\title{
Spinal Myoclonus in Association with Herpes Zoster Infection: Two Case Reports
}

\author{
G. S. DHALIWAL and D. A. McGREAL
}

SUMMARY: Two cases of segmental spinal myoclonus, attributed to herpes zoster infection, are presented. The findings support the suggestion made by Campbell and Garland (1956) that "subacute myoclonic spinal neuronitis" is of viral origin. Both patients were receiving immuno-suppressive treatment when the myoclonus developed. The value of carbamazepine in therapy is mentioned.

RÉSUMÉ: Deux cas de myoclonus spinal segmentaire, attribués à une infection d'herpes zoster sont présentés. Les observations supportent la suggestion faite par Campbell et Garland (1956) que la névrite myoclonique spinale subaigue est d'origine virale. Les deux patients recevaient un traitement immuno-suppressif quand le myoclonus s'est développé. La valeur du carbamazepine en thérapie est soulignée.

From the Department of Pediatrics, The Hospital for Sick Children, Toronto, Ontario, M5G IX8, Canada.

Reprint Address: Dr. D. A. McGreal, The Hospital for Sick Children, 555 University Avenue, Toronto, Ontario M5G 1X8, Canada.
Myoclonus occurs in many lesions of the nervous system at different levels. It may be a manifestation of diffuse neuronal involvement as in Tay-Sachs disease and subacute sclerosing panencephalitis; it may be due to relatively restricted lesions of the brain stem and cerebellum as in the progressive myoclonic epilepsy of Unverricht and Lundborn or the dyssynergia cerebellaris myoclonica of Hunt; or it may be due to lesions of the spinal cord (Castaigne et al., 1969). In some types of myoclonus no pathological lesion can be demonstrated. The subject has been reviewed extensively by Bradshaw (1954) and Aigner and Mulder (1960).

Campbell and Garland (1956) described three cases of myoclonus due to probable viral neuronitis of the spinal cord and called the condition "subacute myoclonic spinal neuronitis." Bradshaw (1969) described another similar case and postulated a viral etiology. The present paper concerns two cases of myoclonus where the etiological agent is thought to be the varicellazoster virus invading the spinal cord.

\section{CASE REPORTS}

Case 1

A 17-year-old white girl developed chronic renal failure following glomerulonephritis in 1966 when she was 10. In November 1972 she had a renal transplant which was rejected and in June 1973 she had another transplant which has been successful up to the present time. She had been receiving immunosuppressive therapy - azathioprine and prednisone - and about five weeks after the transplant typical zoster skin lesions appeared in the perineal region, later spreading to the right buttock. Sixteen days later she complained of painful involuntary movements of the proximal parts of the lower limbs and at this time the zoster rash was extensive in the perineum and over her right buttock. At this time examination revealed frequent, jerking thigh movements which were at times synchronous and which spread upwards to cause massive shock-like movements of the thighs, pelvis and lower trunk. The movements were aggravated by sensory stimuli such as touch and persisted during sleep, frequently waking the patient. There was no weakness, the tendon reflexes were symmetrical and the plantar responses were flexor. The abdominal reflexes were symmetrical and sensory functions were intact but she had urinary incontinence associated with a monilial cystitis. Laboratory investigations showed normal serum $\mathrm{Na}, \mathrm{K}, \mathrm{Ca}, \mathrm{P}, \mathrm{Mg}, \mathrm{HCO}_{3}$ and $\mathrm{pH}$. The BUN was $54 \mathrm{mg} . \%$ and creatinine $4.4 \mathrm{mg} . \%$. Examination of vesicular fluid obtained from the skin lesions showed the presence of a herpes group virus.

The painful movements were treated with meperidine, morphine, chlorpromazine, diazepam and carbamazepine but only the latter provided substantial relief from the pain and the movements. When the drug was discontinued the symptoms recurred, but when it was restarted there was again relief.

Subsequent clinical follow-up showed that the patient had made a complete neurological recovery.

\section{Case 2}

An 18-year-old white girl had chronic renal failure due to chronic pyelonephritis and for 4 years had 
undergone regular hemodialysis. Two renal transplants had been unsuccessful. She was admitted on July 23, 1973 for repair of a false aneurysm of the left saphenous vein following dialysis shunt. A week later, a rash appeared on the right shoulder and adjacent areas of the neck and chest, the appearance and distribution of the rash being consistent with herpes zoster infection. About a week after the rash appeared she started having myoclonic jerks involving the right shoulder and upper arm and these persisted for about two weeks. The movements remained localized and recurred with variable frequency, at times being fairly continuous but at other times none might occur for an hour or more. They were aggravated by sensory stimuli and also occurred during sleep. Pain was present with the jerks but was not as severe as that occurring in Case 1 and relief was obtained with meperidine and diazepam. The remainder of the neurological examination was negative.

Laboratory investigations showed normal serum $\mathrm{Na}, \mathrm{K}, \mathrm{Cl}, \mathrm{Ca}, \mathrm{P}, \mathrm{Mg}$ and $\mathrm{HCO}_{3}$ and normal $\mathrm{pH}$. The BUN was $63 \mathrm{mg} . \%$ and the creatinine 10.8 $\mathrm{mg} . \%$. Electron microscopy of the vesicular fluid obtained from the rash showed the presence of a herpes group virus and the varicella-zoster virus was isolated in cell culture.

Regular hemodialysis has been continued and the patient functions well without any neurological deficit.

\section{DISCUSSION}

The term "subacute myoclonic spinal neuronitis" was first used by Campbell and Garland (1956) when they described three patients having painful myoclonic movements of the lower limbs and lower trunk. In two of these patients there was ascending involvement of the spinal cord with paralysis of respiratory muscles, and in both cases post-mortem examination was suggestive of viral neuronitis of the spinal cord. The lesions were primarily confined to the gray matter of the cord, with perivascular cuffing and microglial nodules, but with inconspicuous damage to neurons. No inclusion bodies were seen and no virus was isolated. The third patient, who survived, had an upper respiratory infection preceding the onset of myoclonus, and the authors postulated a viral etiology for all three patients. They also mentioned the possible role of X-radiation since in both the patients who died, radiation therapy was given six weeks before the onset of myoclonus, in one patient for ankylosing spondylitis and in the other for Hodgkin's disease in the chest. It is possible that the radiation reduced the immune responses of the nervous system to viral infection and in this respect it is interesting that both patients reported here were receiving immuno-suppressive medication. Bradshaw (1966) described the case of a young woman who developed painful jerks of thighs and lower trunk following an upper respiratory infection. Improvement occurred with benuride therapy.

There is experimental evidence in favor of myoclonus of spinal cord origin, since Newcastle virus infection in cats causes mycolonus as a prominent manifestation of the infection (Luttrel and Bang, 1958).

In both of the patients described here, the myoclonic movements started after the appearance of the zoster lesions, lasted for two to three weeks and have not recurred. In addition, the areas involved in the myoclonus corresponded to the site of the rash; in case one the vesicular lesions were distributed over the perineum and right buttock and the myoclonus involved thighs, pelvis and lower trunk. The significance of the urinary incontinence is uncertain. In case two both rash and myoclonus involved the right shoulder region. In both cases the skin lesions and electron microscopy studies were consistent with the varicellazoster group of viruses and this virus was isolated in cell culture in case 2 . A rise in complement fixing antibodies cannot be expected in patients with chronic renal disease who are receiving dialysis and immunosuppressive therapy. It is known that segmental involvement of the spinal cord by zoster infection can cause transverse myelitis and lower motor neuron paralysis (Editorials, British Medical Journal 1970; Thomas and Howard 1972) but the literature does not mention spinal cord myoclonus as being due to the vericella-zoster virus.

The mechanism of spinal cord myoclonus is uncertain. Walshe (1920), in a case of encephalitis lethargica, noticed that the myoclonus was later followed by a lower motor neuron paralysis of the arm, and that by that time the myoclonus had stopped, suggesting that the anterior horn cell might be the seat of the myoclonus. Bradshaw (1954) suggested that intercalated neurons in the posterior horn of the spinal cord may be affected in "essential myoclonus," setting up an excitatory state in the stretch reflex arc and resulting in the production of involuntary movements from normal afferent impulses. In our patients, the fact that the myoclonus was induced or increased by sensory stimuli, and that there was no muscle weakness, might support the mechanism suggested by Bradshaw (1954) but this is clearly conjectural in the absence of neuropathological evidence. An interesting observation was that the pain and movements in Case 1 were improved by the use of carbamazepine. Bradshaw (1954) described three patients in whom improvement in the myoclonus occurred with phenacetamide.

\section{REFERENCES}

AIGNER, B. R., and MULDER, D. W. (1960). Myoclonus. Archives of Neurology, 2, 600-615.

BRADSHAW, J. P. P. (1954). A study of myoclonus. Brain, 77, 138-157.

BRADSHAW, J. P. P. (1969). Cited in Handbook of Clinical Neurology, Amsterdam, North-Holland Publishing Co., 1, 277-292.

CAMPBELL, A. M. G., and GARLAND, H. (1956). Subacute myoclonic spinal neuronitis. Journal of Neurology, Neurosurgery and Psychiatry, 19, 268-274.

CASTAIGNE, P., CAMBIER, J., and LAPLANE, D. (1969). Myoclonies rythmées 
segmentaries d'origine médullaire. A propos de deux observations. Revue d'OtoNeuro-Ophtalmologie, 41, 241-250.

EDITORIAL (1970). Paralysed hemidiaphragm and shingles. British Medical Journal, 1, 382-383.
EDITORIAL (1970). Paralysis in herpes zoster. British Medical Journal, 2, 379.

LUTTREL, C. N., and BANG, F. B. (1958). Newcastle disease encephalomyelitis in cats: 1. Clinical and pathological features. Archives of Neurology and Psychiatry, 79, 647-657.
THOMAS, J. E., and HOWARD, F. M., Jr. (1972). Segmental zoster paresis - a disease profile. Neurology, 22, 459-466.

WALSHE, F. M. R. (1920). On the symptomcomplexes of lethargic encephalitis with special reference to involuntary muscular contractions. Brain, 43, 197. 